\title{
Integration around regional development goals Discourse concerning the European Social Fund utilisation in Opolskie region
}

\begin{abstract}
The article presents an analysis of the discourse of the European Social Found (ESF) component in Regional Operating Programme of Opolskie Voivodeship present in regional media. The paper shows multilevel institutional conditions for the regional ESF discourse that concerns the integration around regional development goals. Next, it includes an analysis of the EFS discourse in regional media. The comparison of regulations and regional media discourse shows important discrepancies between them, which becomes an argument for considering regional media discourse on ESF as somewhat independent from institutional regulations. The article also shows that the integration around regional development goals is not the main focal point in it and is not realised precisely in according to the external regulations.
\end{abstract}

Keywords: regional development, European Social Found, Discourse Analysis, Opolskie Voivodeship.

\section{Introduction}

For the discourse analysis of ESF utilisation in Opolskie region, it is important to place the region on a vertical scale of the European Union, the Republic of Poland and Opolskie Voivodeship. What analytically binds together those entities of different size is the institutional approach to the region. In this perspective, a region is seen in "the categories of relational links of space, institutions, regional population, and the symbols and myths generated in the public discourse" (Poniedziałek 2015: 85).

In a region seen from this perspective, regional government is conditioned in defining its aims by larger-scale institutions such as the state and the European Union. In the case of Polish regions, these conditions are determined by the national legal system, as well as the European Regional Policy, European Cohesion Policy, and the European Social Fund. However, those top-down determinations are not applied automatically, but they are reshaped in the region. The reshaping 
and changes are not merely the result of a rational decision process. Instead they are conditioned by the (institutional) character of the region, that consists of such factors as long-term processes, regional identity (Paasi 2001: 7-28; 2003: 475-485) and established institutional patterns. Moreover, the regional policy formed by the regional government is not implemented without reflection. Other social actors may assume different attitudes towards it, from total reinforcement to full opposition.

In the case of Opolskie Voivodeship, the main participants of the discourse related to ESF are the Office of the Marshal of the Opolskie Voivodeship as the managing institution for the Regional Operational Programme (ROP), and the Provincial Labour Office in Opole as the intermediary institution for the regional component of the Operational Programme Knowledge Education Development (OP KED), as well as regional media and social actors.

In this paper, I am using the term "discourses" as proposed by James Paul Gee, who defines them as:

different ways in which we humans integrate language with non-language 'stuff', such as different ways of thinking, acting, interacting, valuing, feeling, believing, and using symbols, tools, and objects in the right places and at the right times so as to enact and recognize different identities and activities, give the material world certain meanings, distribute social goods in a certain way, make certain sorts of meaningful connections in our experience, and privilege certain symbol systems and ways of knowing over others (Gee 2001).

The discourses exist in the world as social practices, mental entities and material entities (Gee 2001: 23). Thus, discourse analysis:

focuses on the thread of language [...] used in the situation network. Any piece of language, oral or written, is composed of a set of grammatical cues or clues (Gumperz 1982) that help listeners or readers (in negotiation and collaboration with others in an interaction) to build [...] interlinked 'representations', that is, 're-presentings' (Gee 2001: 85).

Its aim is to search for patterns and connections in and across utterances to hypothesise about the ways that meaning is constructed and organised (Gee 2001: 99). One way of reaching this goal is to focus on the "ways in which different sorts of texts and styles of language intermingle to create and transform meaning" (Gee 2001: 41), i.e. intertextuality.

In the present paper, I want to show how the regional government is trying to involve non-governmental actors (entrepreneurs, NGOs etc.) in activities that contribute to regional development goals. In my analysis, I am focusing on the public discursive aspects of this activating and encouraging, that takes place in Opolskie Voivodeship. The Opolskie region is placed on a multilevel scale. For the purpose of my analysis, the scales that must be taken under consideration are: the European Union, the Republic of Poland and the local government of Opolskie 
Voivodeship. All these different scale entities meet at the regional level and shape the discourse around ESF in Opolskie. The reason why the research on ESF in a region is so interesting is the fact that it mainly involves actions that, in principle, are not economically profitable for those who engage in their implementation. The second reason is that ESF operations involve non-governmental actors who are contesting for the funds in order to implement projects that need to be better than those of other contestants and be selected by a competent managing authority (that is the Voivodeship's Marshal Office or the Provincial Labour Office). Hence the intertextual lens promises to be the most valid approach to the problem.

The European Social Fund is Europe's main instrument for supporting jobs, helping people get better jobs and ensuring fairer job opportunities for all EU citizens. It works by investing in Europe's human capital - its workers, its young people and all those seeking a job ${ }^{1}$.

The simplified explanation of how ESF can be used as an example of regional integration around development goals is that the EU on its part sets funds for different goals, that are aligned to the "Europe 2020" strategy. Those funds are then utilised in member countries and regions. On the other hand, the countries and regions set their own interrelated development goals to follow. The EU regions try to use the goals of the European funds to meet their own goals, to be able to use these funds. Therefore, the utilisation of European funds in the regions should be understood as a way to achieve regional developmental goals.

Every level has its own institutions, which lay down their own regulations. Starting from the top, the European Union (European Parliament and Council (EU) Regulations 1303/2013 ${ }^{2}$ and 1304/2013 ${ }^{3}$ ), the Republic of Poland (The act of July $11^{\text {th }}, 2014$ on the Rules for the Implementation of the Programmes in Cohesion Policy range financed in 2014-2020 financing perspective ${ }^{4}$; Strategy

\footnotetext{
${ }^{1} \mathrm{http}: / /$ ec.europa.eu/esf/main.jsp?catId=35\&langId=en [20.07.2018].

${ }^{2}$ Regulation (EU) No. 1303/2013 of the European Parliament and of the Council of 17 December 2013 laying down common provisions on the European Regional Development Fund, the European Social Fund, the Cohesion Fund, the European Agricultural Fund for Rural Development and the European Maritime and Fisheries Fund and laying down general provisions on the European Regional Development Fund, the European Social Fund, the Cohesion Fund and the European Maritime and Fisheries Fund and repealing Council Regulation (EC) No. 1083/2006.

${ }^{3}$ Regulation (EU) No. 1304/2013 of the European Parliament and of the Council of 17 December 2013 on the European Social Fund and repealing Council Regulation (EC) No. 1081/2006.

${ }^{4}$ Ustawa z dnia 11 lipca 2014 roku o zasadach realizacji programów $w$ zakresie polityki spójności finansowanych w perspektywie finansowej 2014-2020 (Dz.U., 2014, poz. 1146 z późn. zm.).
} 
for the Cohesion Policy Communication for the years 2014-2020 $)$ and the Opolskie Voivodeship (The Development Strategy for the Opolskie Voivodeship until 2020; The Regional Operational Programme for Opolskie Voivodeship ${ }^{6}$; The Communication Strategy of European Funds in Opolskie Voivodeship for 2014 $\left.2020^{7}\right)$.

\section{European regulations}

The first PE Regulation mentioned above is a general act on the European funds and on their main procedures. Its role is to lay down the guidelines for using the European funds to achieve the goals set in the "Europe 2020. A European strategy for smart, sustainable and inclusive growth" ". The second PE Regulation is a specific ESF legal act detailing its prerogatives.

The general act on European funds ${ }^{9}$ emphasises communication as a way to integrate people around strategic developmental goals. Although the main body of the law barely touches on the aspect of activation by mentioning that "the Member States and managing authorities shall be responsible for: a) drawing up communication strategies" ${ }^{\prime 10}$ (also, Article 32(4) refers to letter e) of Article 35(1) and mentions the possibility of using funds for "animation of the community-led local development strategy"). Elaboration of the information and communication

${ }^{5}$ Strategia komunikacji polityki spójności na lata 2014-2020, 30 czerwca 2015 r., http://power.wupopole.praca.gov.pl/wiadomosci/-/asset_publisher/87JXLw8OIbCw/ content/3279823-strategia-komunikacji-polityki-spojnosci-na-lata-2014-2020/pop up?_101_INSTANCE_87JXLw8OIbCw_viewMode=prin [2.07.2018].

${ }^{6}$ Regionalny Program Operacyjny Województwa Opolskiego na lata 2014-2020. Wersja $\mathrm{nr}$ 3.0, http://rpo.opolskie.pl/wp-content/uploads/RPO-WO-2014-2020_wersja-nr-3-lipiec-2018.pdf [15.07.2018].

${ }^{7}$ Strategia komunikacji funduszy europejskich w województwie opolskim na lata 2014-2020. Dokument zatwierdzony przez Komitet Monitorujący Regionalny Program Operacyjny Województwa Opolskiego na lata 2014-2020 uchwałą nr 182/2018 z dnia 10 maja 2018 r., http://rpo.opolskie.pl/wp-content/uploads/Strategia-komunikacji-funduszy-europejskich-2018.pdf [10.07.2018].

${ }^{8} \mathrm{http}: / /$ ec.europa.eu/eu2020/pdf/COMPLET\%20EN\%20BARROSO $\% 20 \% 20 \% 20$ 007\%20-\%20Europe\%202020\%20-\%20EN\%20version.pdf

${ }^{9}$ Regulation (EU) No 1303/2013 of the European Parliament and of the Council of 17 December 2013 laying down common provisions on the European Regional Development Fund, the European Social Fund, the Cohesion Fund, the European Agricultural Fund for Rural Development and the European Maritime and Fisheries Fund and laying down general provisions on the European Regional Development Fund, the European Social Fund, the Cohesion Fund and the European Maritime and Fisheries Fund and repealing Council Regulation (EC) No. 1083/2006.

${ }^{10}$ Article 115(1) (a). 
strategy can be found in Annex XII. There, the EP and EC specify what means of communication, information and partners involvement are required.

Amongst others, these measures are as follow:

(a) organising a major information activity publicising the launch of the operational programme or programmes $[\ldots]$;

(b) organising one major information activity a year which promotes the funding opportunities and the strategies pursued and presents the achievements of the operational programme or programmes, including, where relevant, major projects, joint action plans and other project examples ${ }^{11}$.

The subsequent clause states that the managing authority should involve the following partners in its communication and information efforts:

(a) competent urban and other public authorities;

(b) economic and social partners; and

(c) relevant bodies representing civil society, including environmental partners, non-governmental organisations, and bodies responsible for promoting social inclusion, gender equality and non-discrimination ${ }^{12}$;

(d) educational and research institutions ${ }^{13}$.

The other European regulation ${ }^{14}$, specific to the ESF, outlines further ways of integrating and mobilising social actors around the strategic development goals. According to its preamble,

The mobilisation of regional and local stakeholders should help to deliver the Europe 2020 strategy and its headline targets. Territorial pacts, local initiatives for employment and social inclusion, sustainable and inclusive community-led local development strategies in urban and rural areas and sustainable urban development strategies may be used and supported to involve more actively regional and local authorities, cities, social partners and non-governmental organisations throughout the preparation and implementation of operational programmes ${ }^{15}$.

${ }^{11}$ Annex XII, Point 2.1(2), Regulation (EU) No. 1303/2013 of the European Parliament and of the Council of 17 December 2013 laying down common provisions on the European Regional Development Fund, the European Social Fund, the Cohesion Fund, the European Agricultural Fund for Rural Development and the European Maritime and Fisheries Fund and laying down general provisions on the European Regional Development Fund, the European Social Fund, the Cohesion Fund and the European Maritime and Fisheries Fund and repealing Council Regulation (EC) No. 1083/2006.

${ }^{12}$ Article 5 of Regulation (EU) No. 1303/2013 of the European Parliament and of the Council of 17 December 2013.

${ }^{13}$ Annex XII, Point 2.1(3), Regulation (EU) No. 1303/2013 of the European Parliament and of the Council of 17 December 2013.

${ }^{14}$ Regulation (EU) No. 1304/2013 of the European Parliament and of the Council of 17 December 2013 on the European Social Fund and repealing Council Regulation (EC) No. $1081 / 2006$.

${ }^{15}$ Ibidem, paragraph (23) of the preamble. 
Furthermore, in article 6(2) and (3), it is specified that in a Member States eligible for support from the Cohesion Fund (such as Poland) or in regions under $90 \%$ of average EU27 GDP (such as Opolskie Voivodeship), certain actions can be taken and financed from the ESF. The managing authorities of an operational programme should use adequate amount of funds from the ESF and use it to encourage social partners by "capacity building activities, in the form of training, networking measures, and strengthening of the social dialogue, and to activities jointly undertaken by the social partners" ${ }^{16}$. To encourage the participation of non-governmental organisations, the same authorities should use ESF funds for NGO capacity building ${ }^{17}$. This shows that the European institutions have set a framework for integrating around developmental goals which includes communication and information measures for all European funds, while it also provides for non-discursive possibilities in the case of $\mathrm{ESF}^{18}$, although there still exists the question if the traces of those actions can be found in public discourse.

\section{Polish regulations}

The next level of institutions that shape the discourse on ESF utilisation in Opolskie is national. The main legal documents here are the Partnership Agreement and the Act of July $11^{\text {th }}, 2014$. The Partnership Agreement puts the obligation of creating a horizontal communication strategy for the Cohesion Policy upon the minister competent for regional development. This strategy then serves as a foundation for the communication strategies created by competent managing authorities for each operational programme ${ }^{19}$. The Act is obliging the minister competent for regional development and each managing authority to ensure ample information and promotion of operational programmes. The minister competent for regional development oversees and can issue instruction to the managing authorities.

${ }^{16}$ Ibidem, Article 6(2).

${ }^{17}$ Ibidem, Article 6(3).

${ }^{18}$ This is the main reason why this paper only discusses some part of the issue of integration around development goals in ESF utilisation.

${ }^{19}$ Art. 4 ust 2, pkt 6; art. 5 ust. 1; art. 9 ust. 1, pkt. 12 Ustawy z dnia 11 lipca 2014 roku o zasadach realizacji programów w zakresie polityki spójności finansowanych $w$ perspektywie finansowej 2014-2020 (Dz.U., 2014, poz. 1146 z późn. zm.). 


\section{National Communication Strategy}

"The Communication Strategy of Cohesion Policy for 2014-2020"20 is the national, horizontal document and a model for all EF communication strategies in Poland, including the one from Opolskie Voivodeship. The national communication strategy gives directions on why the information is needed, and about why and how to inform people about the EF.

The main challenges for information and communication operations set in this strategy are to "activate the polish society" 21 and to "eliminate the barriers stemming from the attitudes and beliefs that impede taking advantage of the opportunities offered by the European funds"22. It shows that the search for the obstacles in utilisation of EF should take place among the inhabitants of Poland, who pose the challenges.

The main purpose set for communication of EF in this strategy is to aid the utilization of European funds in order to realise the national development goals $^{23}$. The strategy enumerates detailed goals which include, among others, "1) activating the Polish society in applying for support from EF [... 4, 4) ensuring wide acceptance for development activities carried out with the help of European Funds" 24 . The national communication strategy is strict about applying its general message. It says that "every topic of an informational or promotional campaign and every creative idea should be compliant with the general message, no matter the institution realising an operation or the operational level" 25 . The general message describes the way in which a recipient should perceive the EF and states that: "The European funds support those who, by implementing good ideas, expand the opportunities and improve the quality of life of the inhabitants of Poland" 26 .

The general message, according to the strategy, should be constructed around 4 main topics: the EF, the change leaders, the changes, the effects. The EF should be portrayed as a driving force, an enabler of change; change leaders (beneficiaries) are agents needing help from the EF to realise their ideas of change; changes are

${ }^{20}$ Strategia komunikacji polityki spójności na lata 2014-2020, 30 czerwca 2015 r., http://power.wupopole.praca.gov.pl/wiadomosci/-/asset_publisher/87JXLw8OIbCw/ content/3279823-strategia-komunikacji-polityki-spojnosci-na-lata-2014-2020/pop up?_101_INSTANCE_87JXLw8OIbCw_viewMode=prin [2.07.2018].

${ }^{21}$ Ibidem, p. 7.

${ }^{22}$ Ibidem.

${ }^{23}$ Ibidem, p. 12.

${ }^{24}$ Ibidem.

${ }^{25}$ Ibidem, p.13.

${ }^{26}$ Ibidem (Fundusze Europejskie wspieraja tych, którzy realizując dobre pomysty, zwiększają możliwości i poprawiaja jakość życia mieszkańców Polski). 
the effects of projects executed by the leaders; and the effect is the country-wide development, understood as a collection of benefits for all inhabitants of Poland ${ }^{27}$.

The information and communication on the European funds should present the following roles of EF: help to those who want to develop Poland and its regions; a catalyst of change; support mechanism; support for big and small changes, including personal changes; encouragement for cooperation of the inhabitants of Poland ${ }^{28}$.

The main recipients of the communication about ESF are the change leaders, i.e. the beneficiaries, both actual and potential ${ }^{29}$. This is connected with the prospect of presenting benefits, previously called "the effects", so the strategy puts an equation mark between the effects and the benefits. Three main perspectives on benefits are enumerated. First and foremost, the perspective of "I", which should show the personal experience and gains, the benefits of an active attitude and change to the "I's" closest environment. The second perspective should show community experience, the cooperation paying off in terms of bigger impact and greater gains. The third perspective should present the national and regional changes from a personal viewpoint ${ }^{30}$.

The strong preference given to the first-person perspective is justified in the document by reference to social research, although the strategists seem to overlook the underlining individualism in this resolution. It may be debated whether this way of promoting EFs is especially tempting to actors who involve themselves only for personal gains or aimed specifically at this kind of people, as those who mostly out of altruistic reasons are already active. One justification for such a solution is given in the preface of the strategy, where the authors refer to research data showing that the inhabitants of Poland tend not to see the benefits they can gain from European funds. Another comes from the table that shows the mechanism to reach target groups where prospective beneficiaries and project participants are defined as having a potential (resources, skills) and actively searching for solutions to their own problems or with a low motivation for involvement" ${ }^{\prime 1}$.

\section{Regional Communication Strategy}

The regional version of the national document is called "Communication Strategy for European Funds in Opolskie Voivodeship for 2014-2020"32. This

${ }^{27}$ Ibidem.

${ }^{28}$ Ibidem, p. 14.

${ }^{29}$ Ibidem, p. 15.

${ }^{30}$ Ibidem, p. 16-17.

${ }^{31}$ Ibidem, p. 21 - Posiadający potencjał (zasoby, umiejętności) i aktywnie poszukujący rozwiązań swoich problemów lub o niskiej motywacji do zaangażowania.

${ }^{32}$ Strategia komunikacji funduszy europejskich $w$ województwie opolskim na lata 2014-2020. Dokument zatwierdzony przez Komitet Monitorujący Regionalny Program 
document produced by the competent department of the Marshal Office is based on the national communication strategy. The main difference between these two is the scale, national in the latter and regional in the former. The main challenges that are put forth in the regional strategy are the same as in the national strategy, i.e. activating Polish society and eliminating barriers stemming from the attitudes and beliefs that impede taking the opportunities offered by the European funds.

The main purpose of the regional strategy is slightly different. It is to aid the utilisation of funds from ROP OV 2014-2020 33 in order to realise the regional development goals $^{34}$. That shows that the regional communication strategy applies not to all operations financed from European funds taking place in Opolskie region, but only to those financed from the Regional Operational Programme. Therefore, the detailed purposes are also smaller in scale, instead of activating and ensuring acceptance of all inhabitants of Poland, it is focusing only on the inhabitants of the Opolskie Voivodeship.

This leads to a general message that is narrower in spatial terms: "The European funds help those who, by realising good ideas, enlarge the opportunities and improve the quality of life of the inhabitants of Opolskie Voivodeship". The regional communication strategy also lists supplemental messages for ROP OV 2014-2020, which are representing the region-specific messages. The European funds in Opolskie Voivodeship:

- improve the competitiveness of enterprises and support the development of an innovative, knowledge-based economy;

- affect the improvement of the environment and the protection of cultural and national heritage;

- improve the quality of life of the region's inhabitants by supporting sustainable transport and investments in social infrastructure;

- support personal and professional development of the region's inhabitants through actions in the area of labour market, as well as social inclusion and investment in the education system ${ }^{35}$.

Despite the fact that those messages are identified as region-specific in the document, similar phrases on the European funds can be found in the section "Communication of change" of the national communication strategy. The latter strategy lists messages about change that include statements about introducing Poland into a new era of development based on knowledge, information and innovation (sec. 3), about changing human environment to be friendlier, cleaner

Operacyjny Województwa Opolskiego na lata 2014-2020 Uchwałą nr 182/2018 z dnia 10 maja 2018 r., http://rpo.opolskie.pl/wp-content/uploads/Strategia-komunikacji-funduszy-europejskich-2018.pdf [10.07.2018].

${ }^{33}$ Regional Operational Programme of Opolskie Voivodeship for 2014-2020 (Regionalny Program Operacyjny Województwa Opolskiego na lata 2014-2020).

${ }^{34}$ Ibidem, p. 19.

${ }^{35}$ Ibidem, p. 20. 
and contributing to human well-being (sec. 8), caring about the cultural heritage (sec. 9), supporting social integration and collaborative actions (sec.6) ${ }^{36}$. This shows that the real region-specific messages on European funds in Opolskie Voivodeship's communication strategy include the improvement of competitiveness of enterprises, caring for the national heritage, investments in sustainable transport and social infrastructure, investments in the system of education.

Another important difference between the two communication strategies involve the scheduled period for activating people to apply for European funds. The national strategy anticipates the need for such effort in the years 2015-2020, but the regional strategy anticipates undertaking these activities only in the period of 2015-2019.

The regional strategy is also very specific about the labour division between the regional institutions in regard to communication and information. It also points out that the managing authority should use regional or local media for the purposes of communication ${ }^{37}$. Therefore, the regional discourse analysis material was gathered from regional press releases and articles.

\section{Regional media}

The analysis included all articles printed in NTO (Nowa Trybuna Opolska - the New Opole Tribune) and in WR (Wiadomości Regionalne - the Regional News) between September 2017 and September 2018. In order to be included in the analysis, an article needed to refer to the ESF in Opolskie Voivodeship ${ }^{38}$. NTO is a regional, daily newspaper, while WR is an informational monthly bulletin in a form of a newspaper published by the voivodeship's local government. Both of these papers have their on-line versions. In addition to these printed papers, the news section of the webpage of the regional government ${ }^{39}$ (UMWO News)

${ }^{36}$ Strategia komunikacji polityki spójności na lata 2014-2020, 30 czerwca 2015 r., http://power.wupopole.praca.gov.pl/wiadomosci/-/asset_publisher/87JXLw8OIbCw/ content/3279823-strategia-komunikacji-polityki-spojnosci-na-lata-2014-2020/pop up?_101_INSTANCE_87JXLw8OIbCw_viewMode=prin, p. 14-15 [2.07.2018].

${ }^{37}$ Strategia komunikacji funduszy europejskich $w$ województwie opolskim na lata 2014-2020. Dokument zatwierdzony przez Komitet Monitorujący Regionalny Program Operacyjny Województwa Opolskiego na lata 2014-2020 Uchwałą nr 182/2018 z dnia 10 maja 2018 r., p. 33, http://rpo.opolskie.pl/wp-content/uploads/Strategia-komunikacji-funduszy-europejskich-2018.pdf [10.07.2018].

${ }^{38}$ I was originally aiming also to include the promotional leaflets and folders about the ESF created in Opolskie. However, the small number of available materials (3 leaflets) concerning ESF made the analysis invalid.

${ }^{39} \mathrm{http}$ ://www.opolskie.pl/aktualnosci/ [4.09.2018]. 
was also included in the analysis. Online news went through the same sampling procedure as printed articles, meaning that any article or announcement published in the news section needed to refer to ESF to be included in the analysis ${ }^{40}$. In the period between September $1^{\text {st }}, 2017$ and September 1 ${ }^{\text {st }}, 2018$ there have been 12 articles concerning ESF in NTO and 20 articles in WR (including 16 articles co-financed from the ESF itself). 28 online news articles that were also included in the analysis.

Relatively to the rest of the analysed material, the NTO contained the smallest amount of data on the ESF in Opolskie Voivodeship. The articles were mainly focused on who does what for European money. They are limited to praising the beneficiaries who manage to gain the financing or the regional government which has assigned the money to them. The articles in NTO are mainly addressed to the people of Opolskie regions who could use the projects' operations.

WR contained 20 articles on EFS implementation and utilisation in Opolskie. These are written by the Marshal's Office functionaries. Some of the articles have even been financed from the EFS (until the end of 2017), while some have not (since 2018). The main difference between these two groups of articles is clear, as the EFS-sponsored articles always contain detailed information about the funding scheme.

Between September 1', 2017 and 2018, the number of articles concerning ESF was the highest on the local government news page. The news was authored by officials who report on the events that involve the local government office or actions that are part of the office activity and require the participation of actors from outside of the institution.

In the first step of the regional media analysis, I have categorised the topics in above-mentioned articles and news items and counted them across different source materials. The categorisation is based on both the material contents and their strategy of communication.

The category that includes the highest number of references is the "amount of money". It includes only the references to specific figures in the research material. This category is constructed purely from the research material, as opposed to the prescriptions form communication strategies. It shows that the most frequently discussed matter in communication about ESF is the topic of the money that come from the EU. For every article in NTO there are approx. 1.6 references to the amount of money, compared to 1.1 in UMWO News and 1.0 in WR. It shows that this feature of ESF discourse in Opolskie is so important that, on average, it is represented in every article. The EU money are depicted in different contexts. As a pool available for all who are interested:

${ }^{40}$ The ESF reference need not to be a direct one, the contextual situatedness or vague references were enough to include a material into the research data. 
The largest fund - over PLN 5.6 million went to PUP Opole ${ }^{41}$;

The 'Opole for the Family' programme is 373 million euros earmarked for projects under all four packages of the program ${ }^{42}$.

The amount may also a resource owned by the regional government:

Co-financing of projects from the European Regional Development Fund will amount to about PLN 14.65 million, and their total value (together with their own contribution declared by companies) exceeds PLN 25 million $^{43}$;

Almost PLN 14.3 million of co-financing was allocated by the Opolskie Voivodeship authorities from the EU pool for the region to projects for the elderly and dependent people ${ }^{44}$.

The frequency of referencing the amount of money shows that the money remains the main issue in ESF discourse, despite the communication strategy prescriptions.

The category with the second highest number of references is the "event" category. It includes all references to the events mentioned in researched articles. Table 1 clearly shows the diversity in this category. Starting from the most frequent information about trainings on EU funds, especially concerning announcements and schedules of such trainings, which contain not only the information about a possibility to gain new knowledge but also an accompanying event:

The trainings concern calls for: prevention of skin cancers, prophylactics of osteoporosis, prevention of chronic obstructive pulmonary disease, postnatal depression $^{45}$;

The meeting will present the rules for applying for support under the abovementioned contest (including detailed conditions, selection criteria, indicators). After the meeting, we invite you for individual consultations ${ }^{46}$;

Eligibility of expenditure for projects co-financed by the $\mathrm{ESF}^{47}$.

${ }^{41}$ Największa pula środków - ponad 5,6 mln zł trafiło do PUP Opole - UMWO News, March 29th 2018.

${ }^{42}$ Program 'Opolskie dla Rodziny' to $373 \mathrm{mln}$ euro przeznaczonych na projekty w ramach wszystkich czterech pakietów programu - UMWO News, February 20 ${ }^{\text {th }}, 2018$.

${ }^{43}$ Dofinansowanie projektów z Europejskiego Funduszu Rozwoju Regionalnego wyniesie około 14,65 mln zl, a ich całkowita wartość (wraz z wkładem własnym deklarowanym przez firmy) przekracza $25 \mathrm{mln}$ zl-NTO, March 2 $2^{\text {nd }}, 2018$.

${ }^{44}$ Niemal 14,3 mln zł dofinansowania przeznaczyły władze województwa opolskiego z unijnej puli dla regionu na projekty dla osób starszych i niesamodzielnych - NTO, July $31^{\text {th }}, 2018$.

${ }^{45}$ Szkolenia dotycza naborów na: profilaktyke nowotworów skóry, profilaktyke osteoporozy, profilaktyke przewlektej obturacyjnej choroby płuc, depresji poporodowej - UMWO News, May $10^{\text {th }}, 2018$.

${ }^{46} \mathrm{Na}$ spotkaniu przedstawione zostana zasady ubiegania się o wsparcie $w$ ramach ww. konkursu (m.in. warunki szczegółowe, kryteria wyboru, wskaźniki). Po zakończeniu spotkania zapraszamy na konsultacje indywidualne - UMWO News, October $25^{\text {th }}, 2017$.

${ }^{47}$ Kwalifikowalność wydatków dla projektów wspólfinansowanych z EFS - UMWO News, August 23 ${ }^{\text {th }}, 2018$. 


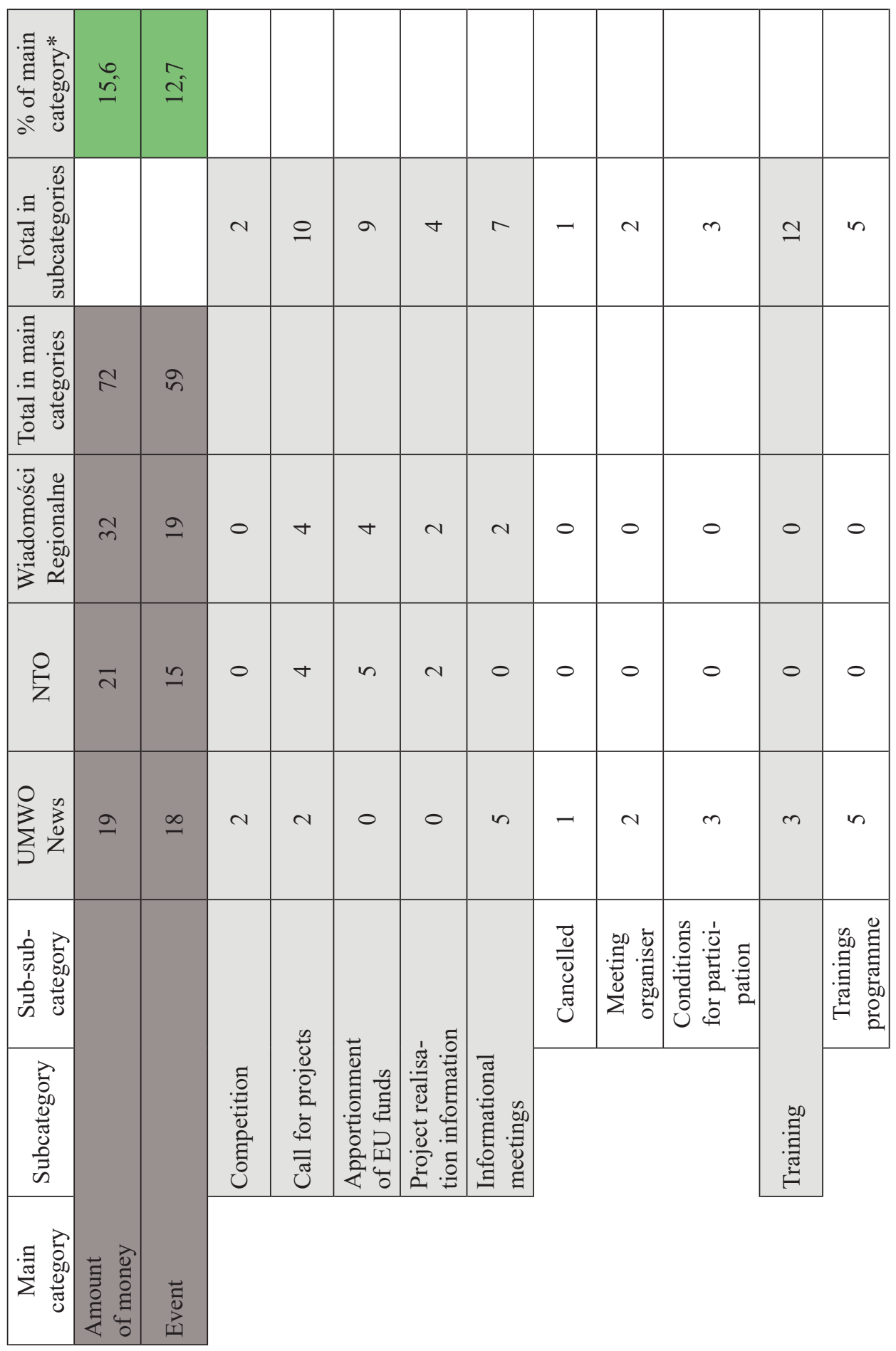




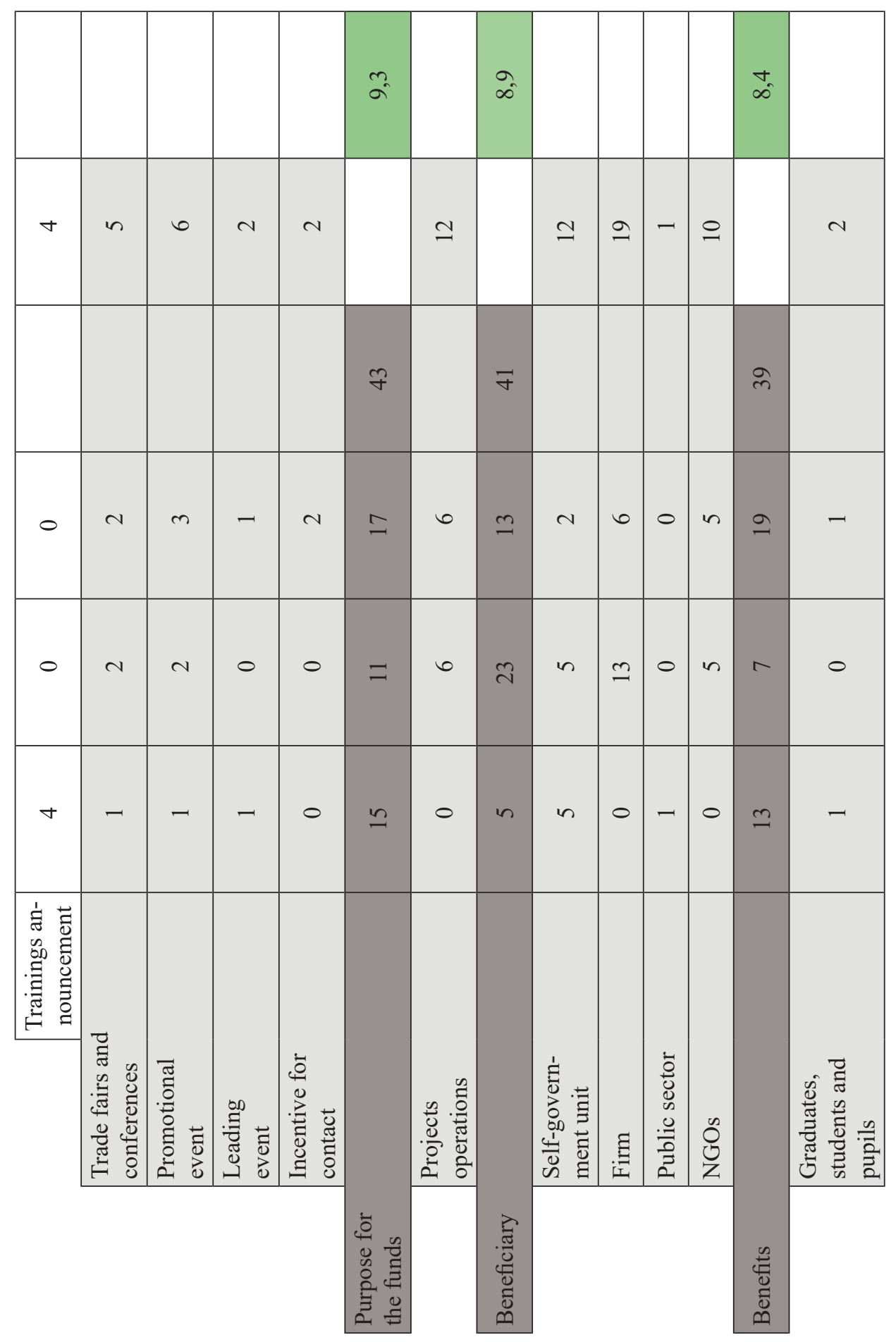




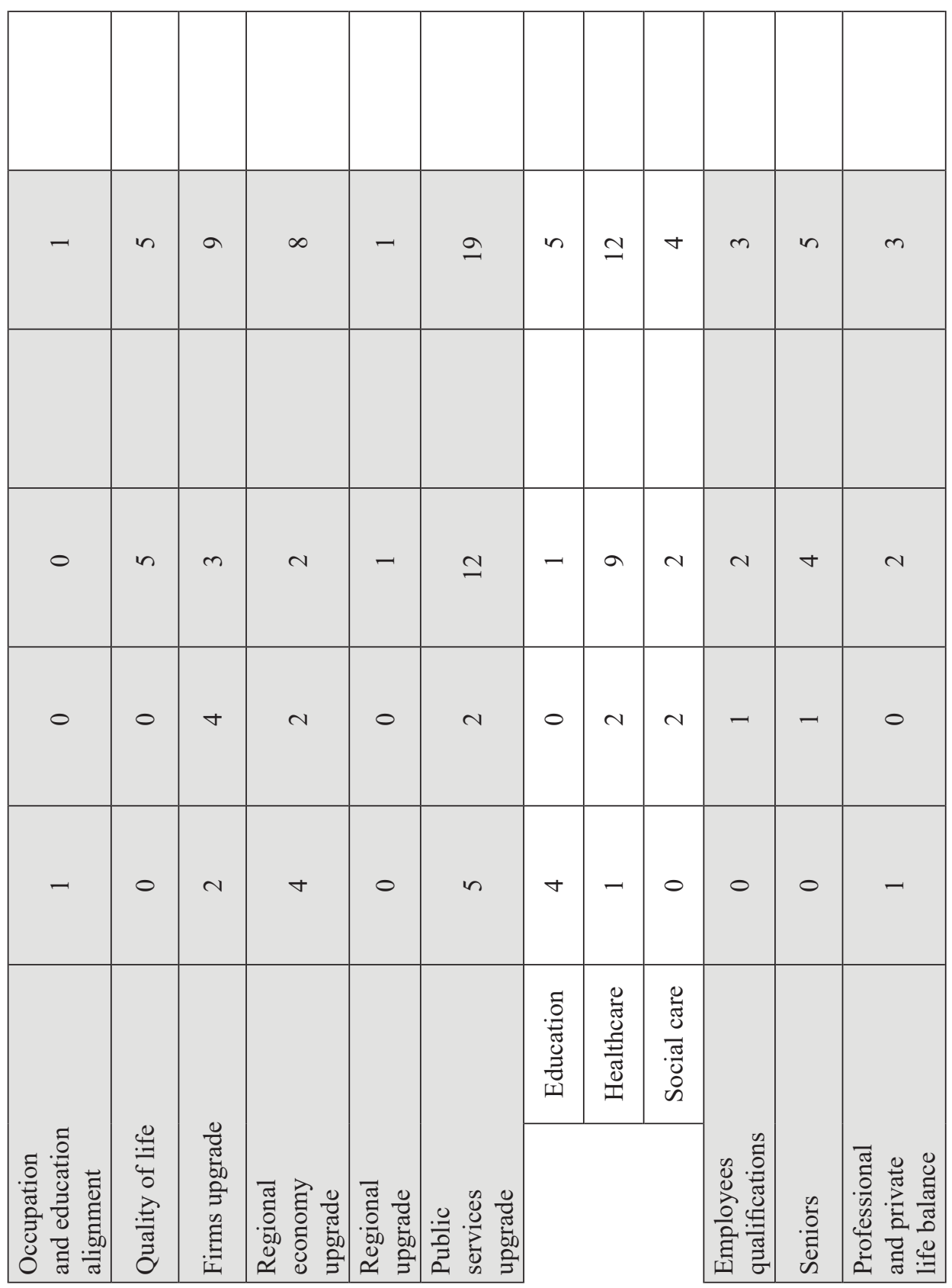


Robert Wieczorek

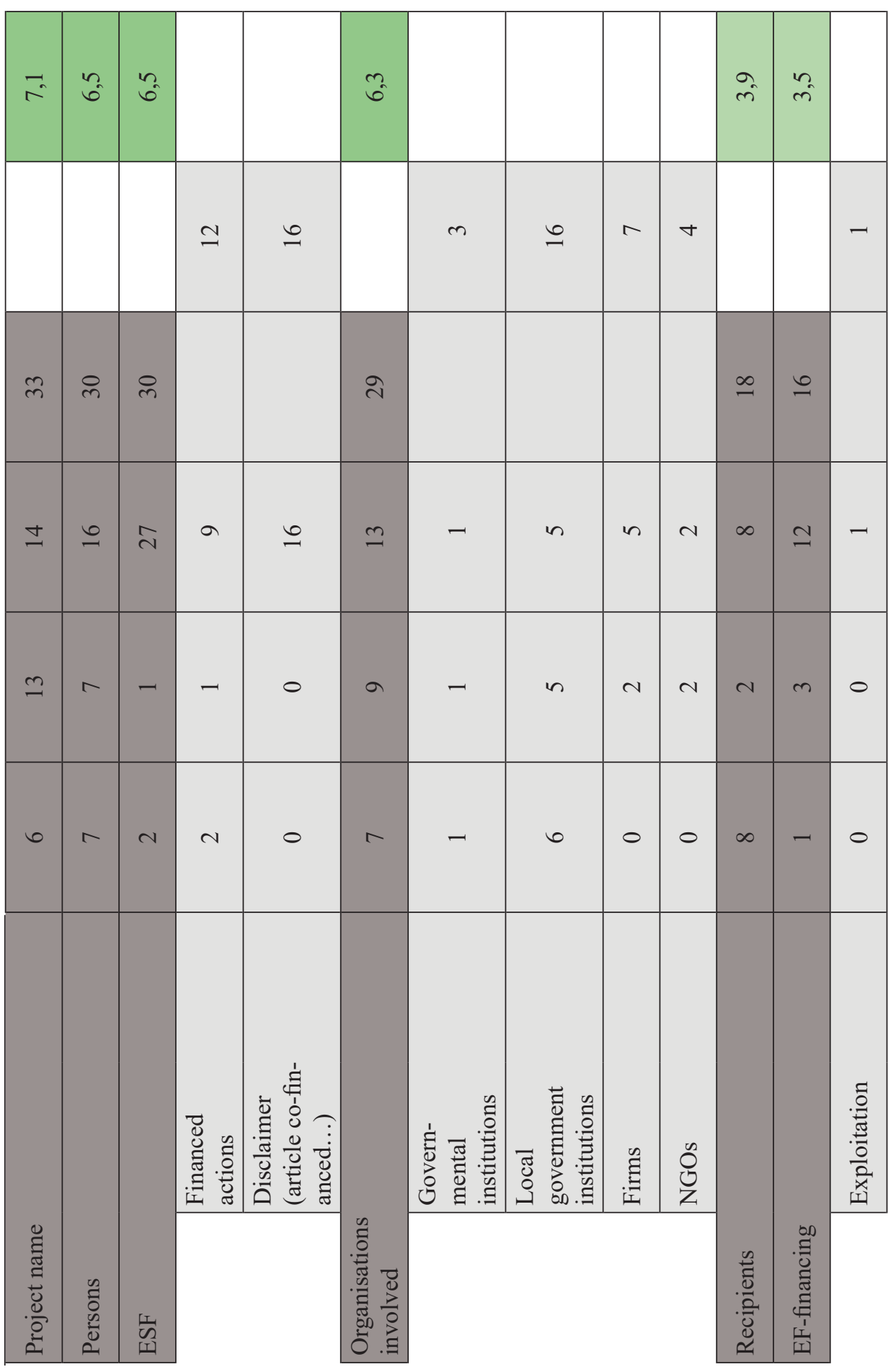




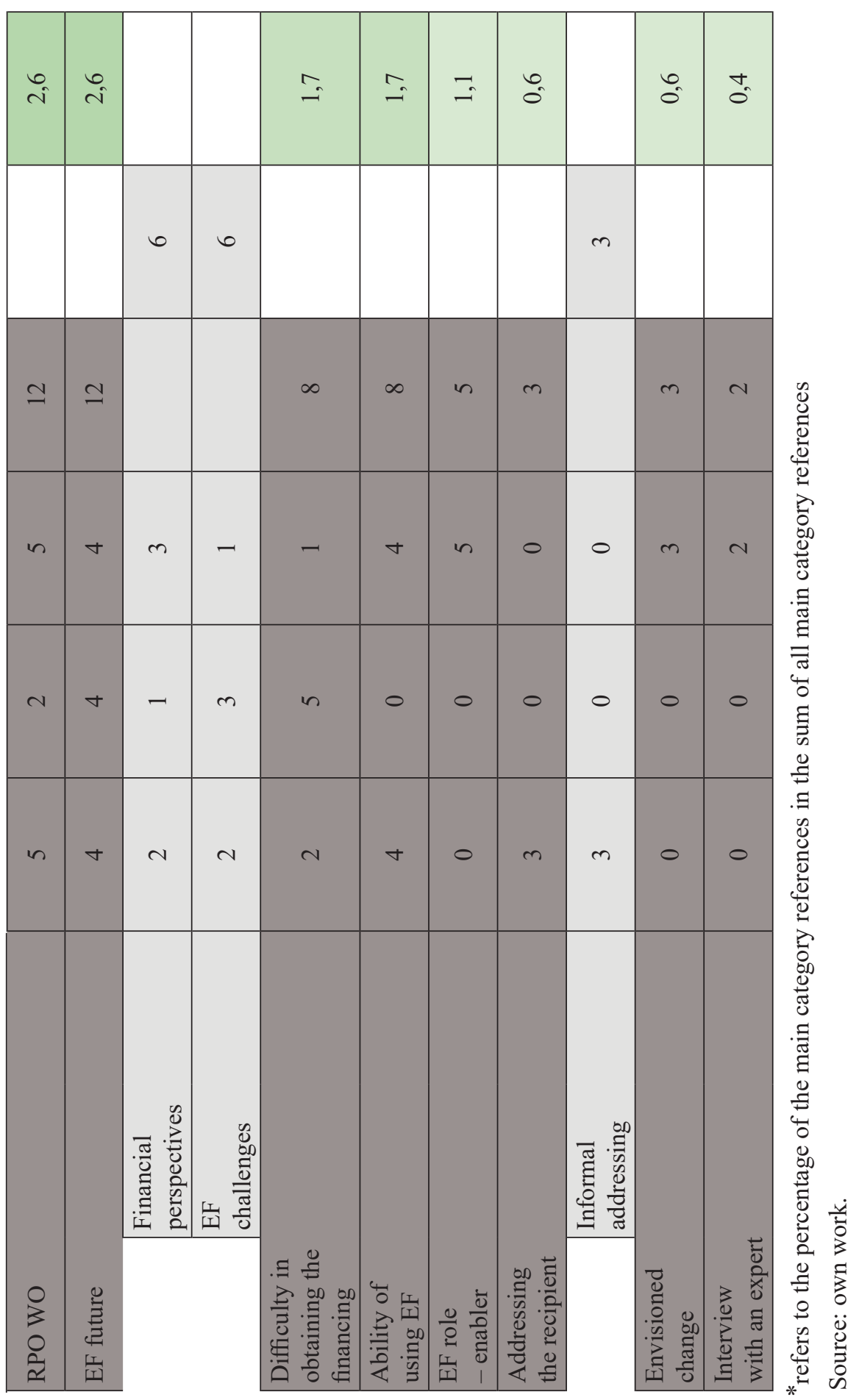


It shows that it is not the only goal of the authors to provide information about the trainings. It is often used to convey other, relevant information, such opening opportunities for applying for EU funds in new contests. This "trainings" subcategory is closely connected with the fourth most frequent subcategory, namely "informational meetings". The distinction between the two is made as the trainings are multi-day workshops allowing the participants to gain new knowledge and abilities, while informational meetings are one-day events meant only to transmit knowledge. The following quote shows what kind of information is provided given during such meetings:

What subsidies for companies are still available? Where to find EU loans without fees and commissions? What has changed in the tax regulations for companies in recent times? You can find out all this at poviat-level meetings, for which entrepreneurs are invited by the marshal of the Opolskie Voivodeship Andrzej $\mathrm{Buła}^{48}$.

The second most frequent subcategory in the event category is "calls for projects". This again is connected with the opportunities of open contests for projects financed by ESF. It often refers to the results of previous calls for projects. This subcategory marks the importance of the distribution of funds in the discourse. It also includes the information about the outcomes of already closed calls.

Another important subcategory of events is the "apportionment of EU funds" category which refers to the reports of the division of EU money between beneficiaries.

The Municipal Health Centre in Gogolin has just signed a contract for co-financing its seventh project ${ }^{49}$;

PLN 14.65 million from the Regional Operational Programme for the Opolskie Voivodeship 2014-2020 was divided by the Marshal's office among entrepreneurs ${ }^{50}$.

The category "event" includes all the events reported in researched material, but it can easily be seen that all of them are shown in a specific context, with getting access to the EU funds being the most prominent. On the one hand, it shows the possibilities of obtaining the know-how and know-what during different types of meetings, while on the other, it directs readers' attention to open calls for projects. At the same time, it is shown who gets money from the EU and how much they

${ }^{48}$ Jakie dotacje dla firm sa jeszcze do wzięcia? Gdzie znaleźć unijne pożyczki bez opłat i prowizji? Co zmieniło się w przepisach podatkowych dla firm $w$ ostatnim czasie? Tego wszystkiego dowiedzieć się można na spotkaniach w powiatach, na które przedsiębiorców zaprasza marszałek województwa opolskiego Andrzej Buła - WR, March 2018: 11.

${ }^{49}$ Gminny Ośrodek Zdrowia w Gogolinie właśnie podpisat umowę na dofinansowanie siódmego projektu - WR, September 2018: 5.

50 14,65 mln zł z Regionalnego Programu Operacyjnego Województwa Opolskiego 2014-2020 podzielit Urząd Marszałkowski dla przedsiębiorców - NTO, March 2 ${ }^{\text {nd }}, 2018$. 
get as examples of success. The second most frequent category is showing what the money was or can be spent on, as well as who the main beneficiaries were.

The third most frequent category includes different purposes for the EU funds that can be found in the regional discourse. The table above shows that in some cases the purposes are put in a narrower sense, as project operations. The main category refers to regional-scale activities, defined in general terms, that are or will be realised with the support of EU funds. Following quotes are examples of such purposes:

The aim of both projects is the same: to provide the sick, the disabled, often lonely, with access to medical care ${ }^{51}$;

In August, the full pool of money was not used. 'Financing of this type of investment supports our actions in the «Opole for the family». Projects that will be implemented by entrepreneurs within this call will not only help to create care places for the youngest inhabitants of our region, but also help their parents reconcile their professional and private lives', says Andrzej Buła, the Marshal of the Opolskie Voivodeship. Within the framework of this call, you can get financing for investments in infrastructure and installations ${ }^{52}$.

The "project operations" subcategory refers to more specific actions that are taken up by the beneficiaries during their project realisation period. They name specific activities, places and times when they will be implemented:

Euromedyk wants to organise a comprehensive range of health services addressed to elderly, dependent people, at risk of poverty or social exclusion. A total of 130 people will take part in them, 65 in each cycle, which will last half a year. Free care is planned in the project both in the homes of the disabled and at Euromedyk's headquarters, which has a full range of medical and rehabilitation facilities (including an indoor swimming pool) ${ }^{53}$;

The programme will last until 2019. A variety of services are provided to women, including: educational meetings for pregnant women who have not completed

${ }^{51}$ Cel obu projektów jest ten sam: zapewnić ludziom chorym, niepetnosprawnym, często też samotnym, dostęp do opieki medycznej - WR, September 2017: 5.

${ }^{52} \mathrm{~W}$ sierpniu, nie wykorzystano petnej puli pieniędzy. 'Finansowanie tego rodzaju inwestycji wspiera nasze działania w programie "Opolskie dla rodziny». Projekty, które będa w ramach tego naboru realizować przedsiębiorcy, nie tylko przyczynia się do utworzenia miejsc opieki dla najmłodszych mieszkańców naszego regionu, ale mają też stużyć godzeniu życia zawodowego i prywatnego ich rodzicom' - mówi marszałek województwa opolskiego Andrzej Buła. W ramach tego naboru można dostać dofinansowanie na inwestycje $w$ infrastrukture $i$ wyposażenie miejsc - WR, September 2017: 10.

${ }^{53}$ Euromedyk chce zorganizować kompleksowa ofertę ustug zdrowotnych adresowana do osób starszych, niesamodzielnych, zagrożonych ubóstwem lub wykluczeniem społecznym. Weźmie w nich udziat łącznie 130 osób, po 65 w jednym cyklu, który trwać będzie pót roku. W projekcie zaplanowano bezpłatna opiekę zarówno $w$ domach niepetnosprawnych, jak $i$ w siedzibie Euromedyka, który dysponuje petna baza medyczna i rehabilitacyjna (tacznie z krytym basenem) - WR, September 2017: 6. 
their $21^{\text {st }}$ week of pregnancy; prenatal tests for pregnant women under 35; midwifery care; lactation counseling; support for child development, including psychosomatic development; support for parents experiencing loss of a child and expecting a child with a lethal defect; vaccinations against pneumococcus; a telephone for life and a house of life; or a 24-hour 'helpline' where women will receive help and/or be directed to a place where she will receive psychological, material, legal support etc..$^{54}$

The category with the fourth largest number of references is the "beneficiary" category, which includes different types of institutions and organisation that are depicted in research material as actors realising projects financed from the EU funds. Companies or private entrepreneurs are the most frequently depicted group, nearly a half of all beneficiaries. Next, over a quarter of all depicted beneficiaries are local government entities, and almost a quarter are NGOs. There is also mention of one public sector organisation. The seventh most frequently referenced category, "persons", is somewhat reverse to the previous one, as it includes and counts all named people, mainly spokespersons or representatives of these abovementioned organisation. This category also includes the managing authorises officials, as well as experts who share their opinions about ESF in the region during interviews. The research material shows that organisations are more important than individuals in utilizing the ESF. Moreover, the comparison of the number of references in "recipient"55 (18 references) and "beneficiary" (41 references) categories shows that organisations which do the work of ESF utilisation are more important than the people who, in principle, are the main target of the ESF. To be clear, it has to be noted that the category "organisations involved" includes a categorised list of nonredundant organisation names taken from other categories.

The category "benefits" includes the good or helpful outcomes that are or should be achieved through the ESF utilisation. It is a category with the sixth largest number of references. The research material gives a wide range of different benefits, but the largest part of it can be included in the subcategory of "public services upgrade". This subcategory involves healthcare, social care and educational

${ }^{54}$ Program potrwa do 2019 roku. Na rzecz kobiet świadczone sa różnorodne ustugi, w tym: spotkania edukacyjne dla ciężarnych, które nie ukończyly 21. tygodnia ciązy; badania prenatalne dla ciężarnych kobiet, które nie ukończyty 35. roku życia; ponadstandardowa opieka położnej; poradnictwo laktacyjne; wsparcie rozwoju dziecka między innymi $w$ zakresie rozwoju psychosomatycznego; wsparcie dla rodziców doświadczonych strata dziecka i oczekujacych dziecka z wada letalna; szczepienia przeciwko pneumokokom; telefon dla życia i dom życia, czy całodobowy 'telefon zaufania', pod którym kobieta otrzyma pomoc i/lub zostanie pokierowana $w$ miejsce, gdzie uzyska wsparcie psychologiczne, materialne, prawne itp. - NTO, August $6^{\text {th }}, 2018$.

${ }^{55}$ This category entails references to people who are getting aid thanks to the ESF utilisation in Opolskie region. 
benefits. Next subcategories, which correspond to each other substantially, include a similar number of references, namely "firms upgrade" and "regional economy upgrade". The former subcategory includes statements such as:

The amount of funding nearly of PLN 14.6 million was awarded to 50 projects of companies, whose implementation is to serve, among others, acquiring new sales markets by these companies and promoting their products at home and abroad ${ }^{56}$; We hope that this money will serve our entrepreneurs to improve the qualifications of their employees, and thus to improve the competitiveness of their companies ${ }^{57}$.

While the latter subcategory includes statements such as:

This is another sum of money from the Regional Operational Programme of the Opolskie Voivodeship, which is meant to reach entrepreneurs and help them develop their businesses and our economy ${ }^{58}$.

The sixth category with the largest number of references includes project names present in the research material. Project names can be found in the context of reporting what was or would be done in each of the projects, but mainly such project names were placed in the context of money and beneficiaries. Some examples of project names found in the research material:

More than PLN 5.5 million has been awarded to the University Clinical Hospital in Opole for the implementation of their project 'My Inner Self - Healthcare Program to Prevent the Incidence of Colon Cancer' ${ }^{59}$;

Prenatal tests are conducted in Opole and Nysa for pregnant women before the age of 35. They can be done as part of the EU project 'Giving birth in Opolskie', lead by 'Healthy Family' 60 .

Also in the sixth place is the "ESF" category, which is constructed from all direct mentions of the ESF. Most of them comes from the WR and is a part of a footnote disclaimer saying that the article is co-financed by the ESF funds. The articles co-financed by ESF ceased to come out since the beginning of the year

${ }^{56}$ Do dofinansowania kwota blisko $14,6 \mathrm{mln}$ zl przyjęto $w$ nim 50 projektów firm, których realizacja ma stużyć m.in. zdobywaniu przez te firmy nowych rynków zbytu i promocji ich produktów $w$ kraju i za granica - NTO, January $4^{\text {th }}, 2018$.

${ }^{57}$ Mamy nadzieję, że te pieniądze postuża naszym przedsiębiorcom do podniesienia kwalifikacji pracowników, a przez to do poprawy konkurencyjności ich firm - WR, October 2017: 9 .

${ }^{58}$ To kolejne pieniądze z Regionalnego Programu Operacyjnego Województwa Opolskiego, które mają trafić do przedsiębiorców i pomóc im rozwijać firmy oraz nasza gospodarke - NTO, January $4^{\text {th }}, 2018$.

${ }^{59}$ Ponad 5,5 mln złotych dofinansowania otrzymat Uniwersytecki Szpital Kliniczny w Opolu na realizacje projektu „Moje wewnętrzne ja - program zdrowotny przeciwdziatajacy zachorowaniom na raka jelita grubego”- WR, September 2017: 5.

${ }^{60}$ W Opolu i Nysie prowadzone sa badania prenatalne dla kobiet w ciaży przed 35. rokiem życia. Można je zrobić w ramach projektu unijnego „Rodziny w opolskim”, którego liderem jest ,Zdrowa Rodzina”- NTO, August 6 ${ }^{\text {th }}, 2018$. 
2018. The second part of the "ESF" references comes from the information on projects and operation financing:

The project is financed by the European Social Fund, and participation in it is free ${ }^{61}$;

Project co-financed by the European Union from the European Social Fund under the Regional Operational Programme of the Opolskie Voivodeship for 2014$2020^{62}$.

All the above-mentioned categories comprise up to $81,3 \%$ of all categorised references. That means that they are the main core of the regional public discourse. As the table shows, there are more information about the integration around development goals in Opolskie Region, but it is rather rare, hence not important in the discourse.

\section{Conclusions}

The analysis has shown the existing conditions for communication on EFS in region and the actual communication about ESF in Opolskie Voivodeship. The prescriptions from communication strategies are not reflected in the research material from regional media. The regional public discourse on EFS talks mainly about money, events, purposes for money, beneficiaries and the benefits. None of these things is a topic stemming from the communication strategies.

Nonetheless, the Opolskie Voivodeship is so far the most efficient region in EF utilisation ${ }^{63}$. This shows not only the efforts of the regional institutions, but also the involvement of the people of the region, the entrepreneurs and NGOs. One way of convincing people to take part in the process of utilisation of EF is the communication. A major part of such communication is the public discourse. In case of regional issues - a regionally-produced one.

The regional discourse analysis on EFS utilisation in Opolskie Voivodeship has shown that it plays a minimal role in integration around the development goals. The contents of regional public discourse mainly serve the informative and reporting functions, while the promotional, activating and integrative functions are marginalised.

Nevertheless, some traces of attempts to integrate regional community around the development goals can be found in the research material. The most frequent category, the money, can be considered as an information about providing

${ }^{61}$ Projekt jest finansowany ze środków Europejskiego Funduszu Społecznego, a udziat w nim jest bezplatny - UMWO News, October 18 ${ }^{\text {th }}, 2017$.

${ }^{62}$ Projekt wspólfinansowany przez Unię Europejska ze środków Europejskiego Funduszu Społecznego w ramach Regionalnego Programu Operacyjnego Województwa Opolskiego na lata 2014-2020 - UMWO News, July 26 $6^{\text {th }}, 2017$.

${ }^{63}$ WR, May 2018: 8. 
resources to act towards meeting these regional goals. The "event" category may be considered as opportunities for partaking and attempts to involve new actors. The category "purpose for the funds" gives information about the regional development goals, as well as the actions, including very specific ones, that are intended to lead to the goals. The "beneficiaries" category shows what kind of regional actors have been integrated around regional goals, while the benefits show which goals have been met during the ESF utilisation.

These leads to a conclusion that it is not only through the public discourse that the region's inhabitants are integrated around regional development goals. The discourse bears some traces of all the actions needed for the integration and its outcomes, but it cannot be responsible by itself for the integration around the regional development goals. Discourse analysis only gives a fragmented picture of the whole process of integration. To get a fuller view, further research is needed.

\section{References}

Gee J.P., 2001, An introduction to discourse analysis. Theory and method, London-New York.

Paasi A., 2001, Europe as a social process and discourse. Considerations of place, boundaries and identity, "European Urban and Regional Studies", 8(1): 7-28.

Paasi A., 2003, Region and place: Regional identity in question, "Progress in Human Geography", 27(4): 475-485.

Poniedziałek J., 2015, Wybrane koncepcje regionu $w$ socjologii polskiej, "Sprawy Narodowościowe. Seria nowa”, 46.

Regionalny Program Operacyjny Województwa Opolskiego na lata 2014-2020. Wersja nr 3.0, http://rpo.opolskie.pl/wp-content/uploads/RPO-WO-2014-2020_wersja-nr3-lipiec-2018.pdf

Regulation (EU) No 1303/2013 of the European Parliament and of the Council of 17 December 2013.

Regulation (EU) No 1304/2013 of the European Parliament and of the Council of 17 December 2013.

Strategia komunikacji funduszy europejskich $w$ województwie opolskim na lata 20142020. Dokument zatwierdzony przez Komitet Monitorujący Regionalny Program Operacyjny Województwa Opolskiego na lata 2014-2020 Uchwałą nr 182/2018 z dnia 10 maja 2018 r., http://rpo.opolskie.pl/wp-content/uploads/Strategia-komunikacjifunduszy-europejskich-2018.pdf

Strategia komunikacji polityki spójności na lata 2014-2020, 30 czerwca 2015 r., http://power.wupopole.praca.gov.pl/wiadomosci/-/asset_publisher/87JXLw8OIbCw/ content/3279823-strategia-komunikacji-polityki-spojnosci-na-lata-2014-2020/pop_ up?_101_INSTANCE_87JXLw8OIbCw_viewMode=prin 
Ustawa z dnia 11 lipca 2014 roku o zasadach realizacji programów w zakresie polityki spójności finansowanych w perspektywie finansowej 2014-2020 (Dz.U., 2014, poz. $1146 \mathrm{z}$ późn. zm.).

\section{Integracja wokół regionalnych celów rozwojowych Dyskurs wykorzystywania Europejskiego Funduszu Społecznego w województwie opolskim}

Zarys treści: Artykuł prezentuje analizę dyskursu dotyczącego Europejskiego Funduszu Społecznego (EFS) w Regionalnym Programie Operacyjnym Województwa Opolskiego, obecnego w regionalnych mediach. Artykuł przedstawia wielopoziomowe uwarunkowania instytucjonalne odnośnie dyskursu na temat EFS, który toczy się wokół integracji celów rozwoju regionalnego. Następnie w artykule dokonano analizy dyskursu EFS $\mathrm{w}$ regionalnych mediach. Porównanie uregulowań z dyskursem medialnym pokazuje istotne rozbieżności między nimi, co staje się argumentem na rzecz pewnej niezależności dyskursu regionalnego od regulacji instytucjonalnych. Artykuł wyjaśnia, że integracja wokół celów rozwoju regionalnego nie jest głównym dążeniem oraz nie jest realizowana zgodnie z uregulowaniami zewnętrznymi.

Słowa kluczowe: rozwój regionalny, Europejski Fundusz Społeczny, analiza dyskursu, województwo opolskie.

Robert Wieczorek

Silesian Institute, Opole, Poland

e-mail: r.wieczorek@instytutslaski.com 